2006 ERSD Annual Report

DOE-BER Environmental Remediation Sciences Project \#1024835

\title{
Biogeochemical Mechanisms Controlling Reduced Radionuclide Particle Properties and Stability
}

\author{
PIs: Jim K. Fredrickson and John M. Zachara \\ Co-PIs: Matthew J. Marshall and Alex S. Beliaev \\ Pacific Northwest National Laboratory, Richland, WA
}

\section{Research Objectives:}

Uranium and Technetium are the major risk-driving contaminants at Hanford and other DOE sites. These radionuclides have been shown to be reduced by dissimilatory metal reducing bacteria (DMRB) under anoxic conditions. Laboratory studies have demonstrated that reduction results in the formation of poorly soluble hydrous oxides, $\mathrm{UO}_{2(\mathrm{~s})}$ and $\mathrm{TcO}_{2} \mathrm{n} \cdot \mathrm{H}_{2} \mathrm{O}_{(\mathrm{s})}$, that are believed to limit mobility in the environment. The mechanisms of microbial reduction of $U$ and Tc have been the focus of considerable research in the Environmental Remediation Sciences Program (ERSP). In spite of equal or greater importance in terms of controlling the environmental fate of the contaminants relatively little is known regarding the precipitation mechanism(s), reactivity, persistence, and transport of biogenic $\mathrm{UO}_{2(\mathrm{~s})}$ and $\mathrm{TcO}_{2(\mathrm{~s})}$.

This research project is elucidating the principal biological and geochemical mechanisms that govern the biomineralization and reactivity of the redox reactive contaminants uranium (U) and technetium (Tc). The results are providing an improved understanding and predictive capability of the mechanisms that govern the long-term immobilization of these contaminants in subsurface environments. The major objectives of this research are to:

- Identify the mechanisms of extracellular $\mathrm{UO}_{2(\mathrm{~s})}$ and $\mathrm{TcO}_{2(\mathrm{~s})}$ nanoparticle formation in metal-reducing Shewanella and determine whether these processes can be generalized to other Gram-negative metal-reducing bacteria including Anaeromyxobacter.

- Determine the biological and geochemical factors governing the reactivity of biogenic $U$ and Tc solids.

- Determine post-reduction biogeochemical processes that act to stabilize or oxidize biosynthetic U(IV) and Tc(IV) nanoprecipitates.

\section{Research Progress and Implications:}

The section summarizes research results following the first two years of a three year project. In the dissimilatory metal reducing bacterium, Shewanella oneidensis MR-1 c-type cytochromes were shown to be essential for the reduction of $\mathrm{U}(\mathrm{VI})$ and formation of extracellular $\mathrm{UO}_{2}$ nanoparticles. In particular, the outer membrane (OM) decaheme cytochrome MtrC, previously implicated in $\mathrm{Mn}(\mathrm{IV})$ and $\mathrm{Fe}(\mathrm{III})$ reduction, directly transferred electrons to $\mathrm{U}(\mathrm{VI})$ as determined by in vitro assay with purified protein. Additionally, deletions of $m \operatorname{tr} C$ and/or omcA significantly affected the in vivo $\mathrm{U}(\mathrm{VI})$ reduction rate relative to wild type MR-1. In both wild type and mutant cells, $\mathrm{UO}_{2}$ nanoparticles accumulated extracellularly to high densities in association with an exopolymeric substance (EPS) (Fig. 1). In wild type cells, this $\mathrm{UO}_{2}$-EPS matrix exhibited glycocalyx-like properties, contained multiple elements of the OM, polysaccharide, and heme containing proteins. Using a novel combination of methods including synchrotron-based X-ray fluorescence microscopy and high resolution immune-electron microscopy, we demonstrated an 
intricate association of the extracellular $\mathrm{UO}_{2}$ nanoparticles with $\mathrm{MtrC}$ and OmcA. This is the first study to directly localize the OM-associated cytochromes with EPS, which contains biogenic $\mathrm{UO}_{2}$ nanoparticles. In the environment, such association of $\mathrm{UO}_{2}$ nanoparticles with biopolymers may exert a strong influence on subsequent behavior including susceptibility to oxidation by $\mathrm{O}_{2}$ or transport in soils and sediments. In particular, the close, interactive molecular association of the nanoparticulate $\mathrm{UO}_{2(\mathrm{~s})}$ with these complex biopolymers in the environment could influence (e.g., slow) the oxidation rate of $\mathrm{U}(\mathrm{VI})$, and prevent the mobilization of the small precipitates as dispersed colloids in pore or groundwater. Collectively, our results imply that the environmental behavior of the biogenic $\mathrm{UO}_{2(\mathrm{~s})}$ will be strongly influenced by this unusual structural association.

Anaeromyxobacter, like Shewanella, is a dissimilatory metal-reducing bacterium (DMRB) indigenous to anoxic soils and sediments with members whose genomes have been completely sequenced. In collaboration with another ERSP-funded project which is focused on identifying the biomolecular mechanisms of metal and radionuclide reduction in Anaeromyxobacter, we have begun a more broad study to understand the processes relative to Shewanella. Preliminary studies indicate that Anaeromyxobacter reduced both $\mathrm{U}(\mathrm{VI})$ or $\mathrm{Tc}(\mathrm{VII})$ and localized $\mathrm{UO}_{2}$ nanoparticles with an EPS matrix similar to Shewanella (Fig. 1). Both Shewanella and Anaeromyxobacter produce a cadre of multi-heme $c$-type cytochromes thought to be responsible for their flexible anaerobic respiratory capacities and electron transfer to metals. Genomic analyses also reveal the presence of multiple hydrogenases and other electron transfer proteins that may also constitute integral parts of the terminal reductase complexes for radionuclide biotransformation. To characterize the role of these proteins in the reduction of Tc(VII), a series of gene deletion mutants in S. oneidensis MR-1 were analyzed for their ability to reduce Tc(VII) when provided with either $\mathrm{H}_{2}$ or lactate as the electron donor. Results of these analyses revealed that the $c$-type cytochromes of $S$. oneidensis MR-1 are not solely responsible for the biogenic reduction of $\mathrm{Tc}(\mathrm{VII})$ with $\mathrm{H}_{2}$ as the electron donor. A Ni-Fe hydrogenase was identified as the physiological uptake hydrogenase since mutants lacking this protein were unable to utilize $\mathrm{H}_{2}$ for the reduction of $\mathrm{Tc}$ (VII) or other metals. The sub-cellular localization of $\mathrm{TcO}_{2}$ nanoparticles produced by either Shewanella or Anaeromyxobacter was also determined by high-resolution transmission electron microscopy (Fig. 2). Interestingly, $\mathrm{TcO}_{2}$ nanoparticles were not found to be localized with an EPS matrix. These findings are anticipated to have important implications for understanding biotransformation, immobilization, and long-term fate of biogenic $\mathrm{TcO}_{2}$ in subsurface environments.

\section{Planned Activities:}

Research during the final year of this 3-year project will focus on:

- Elucidating the significance of EPS association with outer membrane multi-heme $c$-type cytochromes in relation to the reduction of radionuclides \& association with radionuclide nanoparticles.

- Isolate and characterize EPS and determine its capacity for binding metals and radionuclides including reduced nanoparticles.

- Determine the rates of air oxidation of radionuclide nanoparticles and controlling factors.

Given FY07 is the final year, each of these research activities will be completed by the end of the fiscal year. 


\section{Information Access:}

\section{$\underline{\text { Publications }}$}

Fredrickson, J. K., J. M. Zachara, D. W. Kennedy, R. K. Kukkadapu, J. P. McKinley, S. M. Heald, C. Liu, and A. E. Plymale. 2004. Reduction of $\mathrm{TcO}_{4}{ }^{-}$by sediment-associated biogenic Fe(II). Geochim. Cosmochim. Acta 68(15):3171-3187.

DiChristina, T. J., J. K. Fredrickson, and J. M. Zachara. 2005. Enzymology of electron transport: Energy generation with geochemical consequences, Chapter 3. In: Reviews in Mineralogy, Geochemistry; Mineralogical Society of America, vol. 59, ed. J. F. Banfield, J. Cervini-Silva and K. H. Nealson, pp. 27-52. Mineralogical Society of America Geochemical Society, Chantilly, VA.

Fredrickson, J. K. 2005. Between a rock and a hard place: Geomicrobial electron transfer. Environ. Microbiol. 7:475-476.

Fredrickson, J. K. and D. L. Balkwill. 2006. Geomicrobial processes and biodiversity in the deep terrestrial subsurface. Geomicrobio. J. 23(6):345-356.

Marshall, M. J., A. S. Beliaev, A. Dohnalkova, D. W. Kennedy, L. Shi, Z. Wang, M. I. Boyanov, B. Lai, K. M. Kemner, J. S. Mclean, S. B. Reed, D. E. Culley, V. L. Bailey, C. J. Simonson, D. Saffarini, M. F. Romine, J. M. Zachara, and J. K. Fredrickson. 2006. c-Type cytochromedependent rormation of U(IV) nanoparticles by Shewanella oneidensis. PloS Biology 4(8):13241333.

Zachara, J. M., J. K. Fredrickson, R. K. Kukkadapu, and Y. A. Gorby. 2006. Anaerobic microbial-mineral processes with Fe(III) oxides: Experimental considerations and approaches. In: Methods for Investigating Microbial-Mineral Interactions. CMS Workshop Lecture Series, Patricia A. Maurice and Lesley A. Warren, Eds. (In press).

\section{$\underline{\text { Recent Presentations \& Meeting Abstracts }}$}

Fredrickson, J. K., M. J. Marshall, D. W. Kennedy, A. Dohnalkova, A. E. Plymale, D. Saffarini, S. B. Reed, D. E. Culley, M. F. Romine, A. S. Beliaev, Y. A. Gorby, and J. M. Zachara. 2005. Biogeochemical Mechanisms of Uranium and Technetium Reduction. Invited seminar - The 3rd International Environmental Research Center Workshop on Environment and Sustainable Development, Damyang, Republic of Korea.

Fredrickson, J. K., M. J. Marshall, A. S. Beliaev, A. Dohnalkova, D. W. Kennedy, D. Saffarini, K. M. Kemner, M. I. Boyanov, B. Lai, D. E. Culley, S. B. Reed, L. Shi, Z. Wang, J. S. Mclean, V. L. Bailey, C. J. Simonson, M. F. Romine, and J. M. Zachara. 2005. Microbial Metal Reduction: Genomics to Geochemistry. Invited seminar - Purdue University Fall 2005 Department of Agronomy Seminar Series, West Lafayette, IN. 
Fredrickson, J. K., and J. M. Zachara. 2006. Biogeochemical Transformations of Metals: New Mechanistic Insights from Coupled Microbial-Geochemical Research. Invited talk - Georgia Institute of Technology Environmental Systems Microbiology symposium, Atlanta, GA.

Fredrickson, J. K., and J. M. Zachara. 2006. Biogeochemical Transformations of Metals: New Mechanistic Insights from Coupled Microbial-Geochemical Research. Invited speaker - Oregon State University Subsurface Biosphere Initiative 2006 Workshop, Newport.

Fredrickson, J. K., and J. M. Zachara. 2006. Biogeochemical Transformations of Metals: New Mechanistic Insights from Coupled Microbial-Geochemical Research. Invited speaker Molecular \& Cellular Biology College of Biological Science, Univ. of Guelph Seminar Series, Guelph, ON, Canada.

Kennedy, D. W., M. J. Marshall, A. S. Beliaev, A. Dohnalkova, L. Shi, Z. Wang, M. I. Boyanov, B. Lai, K. M. Kemner, J. S. Mclean, S. B. Reed, V. L. Bailey, D. Saffarini, M. F. Romine, J. M. Zachara, and J. K. Fredrickson. 2006. The Role of Shewanella oneidensis MR-1 Outer Membrane $c$-Type Cytochromes in Extracellular $\mathrm{U}(\mathrm{IV}) \mathrm{O}_{2}$ Nanoparticle Formation. Abstract submitted to 106th American Society for Microbiology General Meeting.

Marshall, M. J., A. E. Plymale, S. B. Reed, D. W. Kennedy, A. Dohnalkova, M. F. Romine, A. S. Beliaev, J. M. Zachara, and J. K. Fredrickson. 2006. Biochemical Mechanisms of Technetium(VII) Reduction by Shewanella oneidensis MR-1. Abstract submitted to 106th ASM General Meeting.

Marshall, M. J., A. S. Beliaev, D. W. Kennedy, A. E. Plymale, A. Dohnalkova, L. Shi, Z. Wang, M. I. Boyanov, B. Lai, K. M. Kemner, J. S. Mclean, S. B. Reed, D. E. Culley, V. L. Bailey, C. J. Simonson, D. Saffarini, M. F. Romine, Y. A. Gorby, J. M. Zachara, and J. K. Fredrickson. 2006. Biomolecular Mechanisms of $\mathrm{U}(\mathrm{IV}) \mathrm{O}_{2}$ and $\mathrm{Tc}(\mathrm{IV}) \mathrm{O}_{2}$ Nanoparticle Formation by Shewanella oneidensis MR-1. Abstract submitted to Environmental Remediation Sciences program (ERSP) 1st Annual PI Meeting, Warrenton, VA.

Marshall, M. J., A. S. Beliaev, D. W. Kennedy, A. Dohnalkova, A. E. Plymale, S. H. Thomas, F. E. Loeffler, R. Sanford, S. B. Reed, D. E. Culley, Y. Zhang, D. Saffarini, M. F. Romine, J. M. Zachara, and J. K. Fredrickson. 2006. Biochemical Mechanisms of Technetium(VII) Reduction by Shewanella oneidensis and Anaeromyxobacter dehalogens. Abstract submitted to 11th International Symposium on Microbial Ecology (ISME-11), Vienna, Austria.

Internet features

External recognition for the PLoS Biology manuscript was given by Chemical \& Engineering News "Bacteria Form Uranium Dioxide 'Pearls': Cytochromes in bacterial slime convert soluble uranium to $\mathrm{UO}_{2}$ nanoparticles" (http://pubs.acs.org/cen/news/84/i34/8434bacteria.html). The PLoS Biology research article was also accompanied by a synopsis written by a professional science writer (Liza Gross - "Cultivating Bacteria's Taste for Toxic Waste.")

http://biology.plosjournals.org/perlserv/?request=get-

document\&doi=10.1371/journal.pbio.0040282 


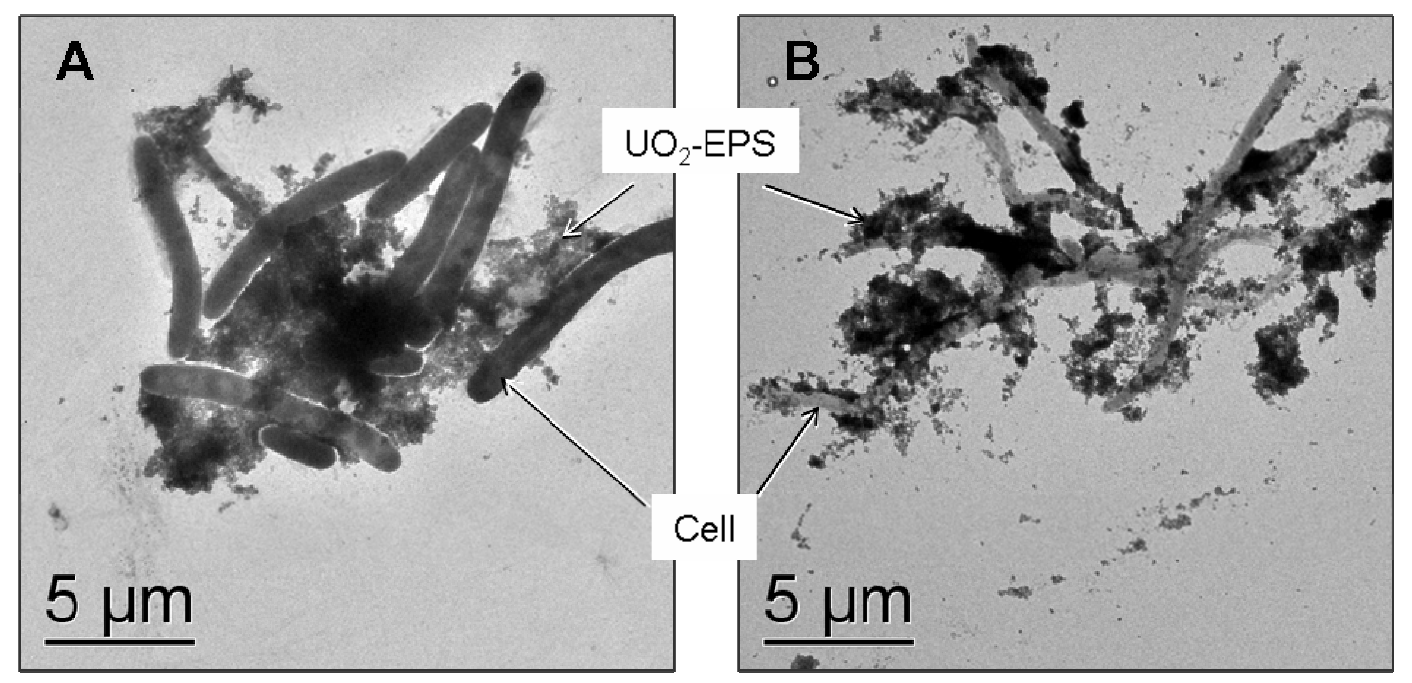

Figure 1. $\mathrm{UO}_{2}$ localization in S. oneidensis MR-1 and A dehalogenans 2CP-C. TEM micrographs prepared from cell suspensions incubated with $250 \mu \mathrm{M}$ uranyl acetate and $10 \mathrm{ml} \mathrm{H}_{2}$ for 24 hours. The localizations of the $\mathrm{UO}_{2}$-EPS are shown in association with intact cells.
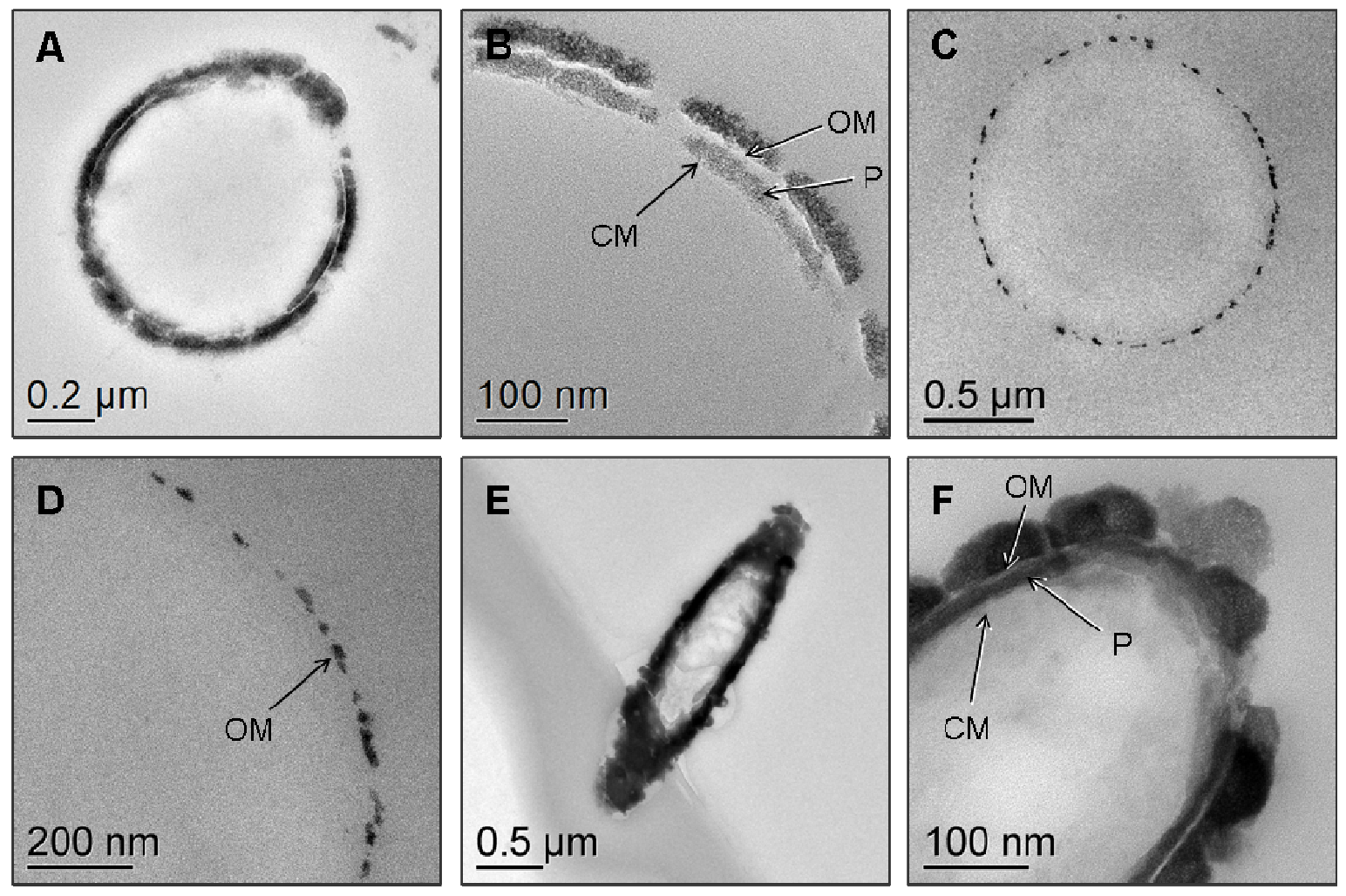

Figure 2. $\mathrm{TcO}_{2}$ localization in $S$. oneidensis MR-1, a Ni-Fe hydrogenase mutant of MR-1, and $A$ dehalogenans 2CP-C. TEM micrographs of thin sections prepared from cell suspensions incubated with $250 \mu \mathrm{M}$ ammonium pertechnetate and $10 \mathrm{ml} \mathrm{H}_{2}$. The localization of $\mathrm{TcO}_{2}$ in MR-1 at 24 hours (A-B) was compared to the Ni-Fe hydrogenase mutant cells (C-D) and 2CP-2 cells (E-F). Locations of the cell membrane (CM), periplasm (P), and outer membrane (OM) are shown. 